\title{
Review
}

\section{A false tree of liberty: Human rights in radical thought}

\author{
Susan Marks \\ Oxford University Press, New York, 2019, x+277pp., ISBN 9780199675456
}

Contemporary Political Theory (2022) 21, S175-S178. https://doi.org/10.1057/s41296021-00511-y; published online 26 August 2021

In A False Tree of Liberty Susan Marks explores the debate over 'the real rights of man' within English political history, and in doing so reveals an alternative understanding of rights, one which is rooted in questions of dispossession, exploitation, and subsistence, as opposed to political liberty.

As set out in the introduction (pp. 4-5, 13-18), this book contributes to the recent debate over the history of human rights, prompted for example by Lynn Hunt's Inventing Human Rights (2007) and Samuel Moyn's The Last Utopia (2010). This debate explores the politics that shapes the origin stories we tell regarding human rights, and how the history of these rights impacts their applicability and universality today. Marks contributes a clear and convincing analysis of an alternative understanding of human rights that can be seen within the history of English politics, 'in which what is important is not the right to property, but instead the dispossession of the unpropertied' (p. 3). She demonstrates how the development of this alternative conception of rights responded to the growth of capitalism by tracing 'the history of an idea and its relationship to change in the material conditions of life' (p. 16) within one particular political culture. The aim of this argument is not to show a continuity of thought about human rights from the past to the present, but rather to show that 'things might have been different' (p. 254) and so reveal new possibilities.

Chapters two to five track the development of this alternative tradition within English politics. Starting with contestations of and changes to patterns and forms of land ownership in the mid- to late fifteenth century, Marks looks to well known works such as Thomas More's Utopia, alongside less studied texts such as Edmund Dudley's The Tree of Commonwealth. She also draws on accounts of enclosure protests and rebellions, such as the 1549 Kett's Rebellion and the Midland Rising. This provides a wider perspective that is well-suited for analysing radical politics, especially in an era without widespread literacy or printing. Chapter four focuses on the English Revolution, examining the radical arguments that flourished amid the upheaval of war. Marks explores the Diggers, who sought to labour collectively

(C) 2021 The Author(s), under exclusive licence to Springer Nature Limited. 1470-8914 Contemporary Political Theory Vol. 21, S4, S175-S178

www.palgrave.com/journals 
on common lands, and the Putney Debates, in which the soldiers of the New Model Army came together to debate the post-Civil War settlement. Her account then jumps forward to the French Revolution debate in England, focusing particularly on the arguments of the pamphlet war between Edmund Burke, Thomas Paine, and Mary Wollstonecraft, the legacy of which continues to shape English politics and our understanding of rights.

Chapters six to ten take a less chronological approach. Though chapter six grows out of the analysis of the pamphlet war in response to the French Revolution, it explores the problem of 'dearth' or scarcity and the subsequent arguments for subsistence that were put forward, with reference to the food riots of this period. This is matched by the discussion of improvement in the following chapter, which unpacks the arguments in favour of the development and consumption of natural resources which were used to justify enclosure and the increasing privatisation of land. Here Marks examines the work of Adam Smith, identifying two interpretations of his arguments regarding the economy, and these two chapters are contextualised within Thompson's conception of the moral economy. Chapter eight explores the justification of right and the interrelation... of nature, history and rights' (p. 185) in the debate regarding the origin and grounding of human rights. Chapter nine develops an original and highly creative exploration of the role of trees in arguments for liberty within English politics, revealing how they were used as both a metaphor and a site of political action. In chapter ten Marks concludes by offering six vignettes that show how the concepts and themes she identifies within this radical tradition of human rights are present within contemporary politicsfrom the repetition of symbols in contemporary protests to the festivals held in memory of the Diggers. This engaging ending highlights the ways in which elements of this alternative understanding of human rights persists within our politics.

The book therefore provides a valuable contribution to the debate over the history of human rights and to wider debates about human rights more generally, especially with regard to their subject and relationship to private property. It also has much to offer those interested in the history of political thought and the history of radicalism. The argument made in A False Tree of Liberty can sit alongside the work of historians such as Christopher Hill, E.P. Thompson, and Malcolm Chase in its examination of the radical tradition in England. And in its engagement with the politics of enclosure there is much in this book to appeal to scholars of environmental history.

One of the strengths of Marks' analysis is the variety of the sources she consults. In addition to political tracts, Marks analyses Shakespeare's plays, the poetry of William Blake, and Oliver Goldsmith, the satirical cartoons of James Gillray, the coins produced by Thomas Spence, and the work of landscape gardeners such as 
Lancelot 'Capability' Brown. The result is an original and engaging argument that is well-supported and which offers a creative response to the difficulty of studying radical politics as well as the means by which these ideas were expressed and circulated in this period. This not only ensures that the book is of interest to scholars from a wide range of disciplines but also illustrates the extent of the influence of political ideas (especially regarding human rights) and the variety of ways in which people express, and are shaped by, their political views.

In the introduction Marks notes that she has 'put to one side the whole huge and properly inseparable topic of empire, for the sake of dwelling on domestic controversies' (p. 12). Her work explores the alternative conception of human rights that grew out of 'a formative time and place ... The relevant place and time were in England in the 1790s' (p. 254). Though there are references to global politics, especially in the final two chapters, the main focus is on English politics and political thought - and given the nature of the debate over resource use, this is frequently localised. The specific politics of place underpins many of the texts and events examined in the book, such as the Digging on St George's Hill or the influence on Thomas Paine of the nearby country estate of the Duke of Grafton, Euston Hall. The scope of the book reflects this focus. Yet the reference to empire could have been unpacked further, especially given the role of empire in the development of capitalism and the 'domestic controversies' to which the politics of empire gave rise. More particularly, the debate over the abolition of slavery could have been cited, as rights were invoked by both sides and many of the authors Marks discusses played a role in this debate. Hannah More, for example, on whose work Marks draws in chapter six, was a key contributor to the abolitionist cause, as seen in Slavery: A Poem from 1788. Highlighting these links, or expanding on the explanation of the focus of the text in the introduction, could have further supported and contextualised Marks' argument.

A False Tree of Liberty offers a fascinating account of the road not taken in the development of human rights, grounded in wide-ranging scholarship yet drawing this material together into a coherent, convincing, and engaging argument. It therefore offers a valuable contribution to our understanding of human rights and also to the radical political tradition in England. In doing so, Marks reveals the work that is still required if we are to realise 'the real rights of all'.

\section{References}

Hunt, L. (2007) Inventing Human Rights. W.W. Norton.

Moyn, S. (2010) The Last Utopia. Harvard University Press.

(C) 2021 The Author(s), under exclusive licence to Springer Nature Limited. 1470-8914 Contemporary S177 Political Theory Vol. 21, S4, S175-S178 
Publisher's Note Springer Nature remains neutral with regard to jurisdictional claims in published maps and institutional affiliations.

Ashley Dodsworth

University of Bristol, Bristol BS8 1QU, UK ashley.dodsworth@bristol.ac.uk 